\title{
THE GEOGRAPHICAL ASSOCIATION
}

\author{
By DR. W. G. V. BALCHIN \\ King's College, University of London
}

$T$ HE annual conference of the Geographical Association recently held at the London School of Economics terminated an eventful year in the history of the society. A diamond jubilee can only occur once, and due note of this important stage has underlain the activities of the Association during the past year. The work of the past sixty years has contributed greatly to the recognition of geography as an academic subject, and a brief survey reveals the transformation which has taken place in this space of time.

During the early and middle part of the nineteenth century, geography was a much neglected subject in Great Britain, despite the great advances which had been made in the realm of exploration and discovery, and in the field of physical geography : and despite, too, the work of Humboldt and Ritter on the Continent, and of Mary Somerville and the activities of the Royal Geographical Society (founded 1830) in Great Britain. The subject was practically nonexistent in the universities; no professor in geography existed at either Oxford or Cambridge, although questions on 'mathematical geography' (largely astronomy) were set in the Mathematical Honours examinations. Oxford also had for some time an optional paper in geography at pass-degree level, but this was linked to history. It is true that professors of geography existed for short periods at University College, London (1835-37), and at King's College, London (1863-76), but little is known of their activities while holding office. In the public and grammar schools of Britain, the education provided was almost wholly classical, and geography was restricted to the Mediterranean-and junior classes. The elementary schools had little time for anything but the three $R$ 's. The status of the subject was undoubtedly very low, and it was probably very badly taught. But in the new training colleges for teachers, geography was given some prominence, and in time the subject began to appear in the newly established middle-class schools. By the 1880's it was being offered by candidates in the Cambridge Local examinations.

Somewhat paradoxically, the same period saw a further decline at higher levels, and this led the Royal Geographical Society to take an active interest. In 1869, largely through Francis Galton, prize medals were offered for competition in the public schools; but this did not prove very successful and the scheme was dropped in 1884. By this time Galton had been joined at the Royal Geographical Society by James Bryce, Douglas Freshfield and H. W. Bates, and these four were largely responsible for the appointment of (Sir) John Scott Keltie as an inspector, in 1884, to make an extensive inquiry into the teaching of geography in Great Britain and America and throughout the Continent. Keltie's report was issued in 1886, and his collection of books and apparatus was exhibited all over the country and stimulated much interest. At the same time, renewed efforts were made to induce the Universities of Oxford and Cambridge to provide lecturers in geography: in this the Society was successful, although at the cost of finding half the salaries. The Oxford appointment was a brilliant success, for in 1887 (Sir) Halford J. Mackinder took up his duties as reader in geography, after having made a name for himself as a University extension lecturer.

Meanwhile, B. B. Dickinson had developed an interest in the subject quite independently and was trying it out with the boys at Rugby School. The scene was now all set for the founding of the Geographical Association, for Dickinson was interested in the "new fangled magic lantern" as an aid to teaching, and he conceived the idea of an exchange system for lantern slides. Discussions with Mackinder and the Royal Geographical Society followed, and as a result a letter was circulated to public schoolmasters in April of 1893 inviting them to a meeting in Oxford. The letter was signed by B. B. Dickinson of Rugby; D. Freshfield of the Royal Geographical Society; H. J. Mackinder, reader in geography at Oxford; T. Field, headmaster of the King's School, Canterbury ; and C. E. B. Hewitt of Marlborough. Although originally called to formulate a scheme for the exchange of lantern slides, the discussion on May 20 led on to the idea of an association, and at a further meeting on August 3, 1893, the. Geographical Association emerged "in order to improve the status and teaching of Geography in Schools", and B. B. Dickinson (somewhat to his surprise, we gather) found himself the first secretary.

The work which had previously been carried out inter alia and somewhat intermittently by the Royal Geographical Society was now taken up wholeheartedly by the new organization, and both the Association and the study of geography have advanced in strength with each passing decade. A membership of a mere handful has now grown to nearly 3,500 , and what was once a dull neglected subject in the schools has now become a vigorous, popular and interesting, and well-established study.

In most public schools a large number (often more than half) of the pupils now prepare for the Geography papers of the General Certificate of Education (Ordinary Level) Examination. An even greater number take geography in the grammar schools, where the subject now ranks fourth in importance after English, French and Mathematics, and more than 75 per cent of the pupils present geography for examination at the Ordinary level. In the Higher level examination, an increasing number of candidates present themselves yearly - in the London examina. tion the numbers have more than doubled since before the Second World War and one advanced level candidate in every five now takes geography. In the universities, too, geography is now a wellestablished discipline-no less than twenty-seven chairs of geography have now been created and more than 175 lecturers and assistant lecturers are to be found in the universities of the United Kingdom. No major institution is, in fact, without a fully staffed and adequately maintained department of geography. The contrast is indeed startling, and the Geographical Association can look back with pride to the part it has played in bringing this about.

The Association has in its time had the support and active interest of many influential personalities : 
in the early days, the president's office was filled by such well-known figures as Sir Halford Mackinder, Douglas Freshfield, Prof. E. J. Garwood, Sir John Scott Keltie, Hilaire Belloc, Prof. Gilbert Murray, Viscount Cecil, Sir John Russell, Sir Richard Gregory, Sir John Myres, Dr. H. R. Mill, Lord Meston and Lord Stamp; while in more recent years Sir Patrick Abercrombie, Sir Cyril Norwood, Sir Alexander CarrSaunders, Sir Harry lindsay, and Profs. H. J. Fleure, L. Dudley Stamp and F. Debenham have officiated. The vital post of secretary passed from B. B. Dickinson to Prof. A. J. Herbertson in 1900, who later had the assistance of Prof. J. F. Unstead. In 1917 Prof. H. J. Fleure became secretary, and for thirty years until 1947 he successfully guided the Association through contrasting phases of difficulty and prosperity. Among geographers, too, the work of Leonard Brooks, C. C. Carter, James Fairgrieve, J. S. Masterman, P. M. Roxby and T. C. Warrington for the Association will not be forgotten.

The aim of the Association "to improve the status and teaching of Geography" has involved it in a great variety of activities. These range from the maintenance of $a_{t}$ well-stocked lending library of books and lantern slides at the headquarters in Sheffield, and the publication of a quarterly magazine Geography (formerly called The Geographical Teacher), to the holding of conferences in the Christmas and Easter vacations and summer schools in the long vacation. Active standing committees deal with geographical matters appertaining to the public and preparatory, and primary and secondary schools. Other committees exist for the teacher-training colleges and further education, while some fifty branches covering the United Kingdom arrange local lecture and excursion "programmes. The Association publishes books and reports relating to geography in the schools and its teaching, and it has conducted many inquiries into examinations and syllabuses. It has worked ardently for special classrooms in schools for geography, encouraged visual aids and assisted the B.B.C. in the broadcests to sehools.

The Association has further fostered the founding and encouraged the growth of the Ship Adoption Society, the Council for the Promotion of Field Studies, and probably most notable of all the Land Utilization Survey. The latter project began with the work of Messrs. J. Fairgrieve, E. E. Field and J. L. Holland : this led to the creation of a standing committee of the Association to deal with land-use mapping. The chairman was Prof. L. Dudley Stamp, who eventually carried the work, by means of the independent Land Utilization Survey, to such a brilliant conclusion. The Geographical Association has also had close and friendly relations throughout its growth with the Ordnance Survey, the Royal Geographical Society, the British Association for the Advancement of Science, the Le Play Society and the Institute of British Geographers (which emerged in the 1930's as a result of the growth of university staffs).

For many members of the Geographical Association the annual conference has become one of the more important events in their geographical calendar. This has been held for many years past in the London Sehool of Economics during the Christmas vacation, and the conference which has just concluded, organized by Dr. W. G. V. Balchin, proved to be one of the most successful and largest yet: nearly four hundred teachers and intending teachers of geography attended the various lectures, exhibitions and excursions arranged for them between December 30, 1953, and January 2, 1954.

In his presidential address to the Association, Dr. O. J. R. Howarth put forward a plea for the greater prominence of Commonwealth studies in the normal geographical syllabus as an intermediate and essential step to a full recognition of world citizenship. The Commonwealth was also the underlying theme of an extensive exhibition organized to show the teacher the range of visual aids now available to assist him in this task. The wide and varied field of interest covered by matters geographical was illustrated by lectures on the work of the Nature Conservaney by Captain Cyril Diver, on recent exploration in the polar regions by Mr. A. Stephenson, and on land and population problems in British Tropical Africa by Mr. R. W. Steel.

As was to be expected, educational aspects figured conspicuously in the proceedings: symposia were arranged on the place and use of Ordnance Survey maps in the primary school, on problems in using visual aids, on geography in further education, and also on specialization in sixth forms-which it was unanimously agreed should be strongly resisted. In addition, Mr. J. B. Goodson discussed sketch maps in the teaching of geography, and Mr. R. C. Honeybone lectured on balance in geography and education. A selection of recent geographical films was shown, including some excellent Kodachrome colour films of field work in Cornwall presented by Prof. P. W. Bryan. On Friday, January 1, the Association joined forces with the Institute of British Geographers and the Royal Geographical Society for the customary annual joint meeting at the Royal Geographical Society. On this occasion the subject could be none other than Everest, and a large audience heard Mr. T. D. Bourdillon and Mr. C. W. F. Noyce lecture on the ascent of 1953 and its significance.

Two popular features of recent conferences again figured prominently in this year's proceedings. A publishers' exhibition of books, maps and appliances for the study and teaching of geography was arranged and more than fifty publishers participated. The founders of the Association would indeed have been surprised, but no doubt extremely gratified, could they have seen the extensive and varied display of geographical material now available. Secondly, the conference was brought to a successful conclusion by an interesting series of excursions : conducted visits were paid to the Map Room of the British Museum, the Central Forecasting Office of the Meteorological Office at Dunstable, and the Port of London; while field work was undertaken in Kent under the direction of Prof. S. W. Wooldridge and Dr. O. J. R. Howarth.

\section{COLOUR-RENDERING PROPERTIES OF FLUORESCENT LAMPS}

$T$

HE phenomena and problems of colour rendering are by no means new. One need only instance the false values often introduced by faulty photographic technique, the strange make-ups necessary for the stage or in front of the ciné and television cameras, or, even commoner experience, the cheerfulness of the bright colours of $a$ sunny day contrasted with the gloomy dullness produced by a hesvily overcest sky. The sudden widespread use of fluores- 